\title{
Effect of chitosan coating on the quality characteristics of rohu (Labeo rohita) fillets during chilled storage
}

\author{
NAZIA NAWAZ ${ }^{1}$, MUHAMMAD ARSHAD ${ }^{1}$, NAUNAIN MEHMOOD ${ }^{1}$, WARDAH HASSAN ${ }^{1}$, \\ SYED ZAKIR HUSSAIN SHAH ${ }^{2}$ AND FARZANA SIDDIQUE ${ }^{3}$ \\ ${ }^{1}$ Department of Zoology, University of Sargodha, Sargodha - 40100, Pakistan \\ ${ }^{2}$ Department of Zoology, University of Gujrat, Gujrat, Pakistan \\ ${ }^{3}$ Institute of Food Science and Nutrition, University of Sargodha, Sargodha, Pakistan \\ e-mail: arshad.sarwar@uos.edu.pk
}

\begin{abstract}
The current work was undertaken to examine the effect of chitosan as a natural edible coating on the quality of rohu (Labeo rohita) fillets during 30 days of chilled storage. The fish fillets were treated with different concentrations of chitosan $(0.1,0.25,0.5$ and $1 \%$ chitosan) and fish fillet without addition of chitosan was kept as control. Sampling was done initially on the $0^{\text {th }}$ day and thereafter at ten day intervals and were examined periodically for water holding capacity (WHC), water extractable protein (WEP), salt extractable protein (SEP), thiobarbituric acid reactive substances (TBARS), $\mathrm{pH}$, total viable count (TVC), psychrotrophic count (PTC) and sensory characteristics. Findings indicated that chitosan coating aided in retaining the quality and extended the shelf life of rohu fillets during refrigerated storage suggesting the suitability of using chitosan as a bio-preservative to extend the shelf life of chilled stored fish.
\end{abstract}

Keywords: Chilled storage, Chitosan, Meat quality, Rohu fillet

\section{Introduction}

Fish is regarded as a worthy source of protein $(15-20 \%)$, vitamins, water soluble nutrients as well as minerals and low in carbohydrates (Tayel, 2016). Fish meat also contains high concentrations of valuable polyunsaturated fatty acids (PUFAs) viz., n-3 and n-6 PUFAs, which are important for human health (Calder, 2004). These PUFAs play an important role in lowering the risk of coronary and cardiovascular diseases (Ghaly et al., 2010) and are also beneficial for brain and eye development in human (Gupta et al., 2009).

However, fish deterioration rate is high as it contains free amino acids, autolytic enzymes having neutral $\mathrm{pH}$ (6-7) and high moisture level (65-80\% water) (Jeyasekaran et al., 2006). This deterioration process is mainly catalysed by heme and non-heme containing proteins, which are present in high quantity in fish meat. Iron and other metals that enhance the spoilage process of fish are also structural part of these proteins (Alishahi and Aider, 2012). This leads to about $15 \%$ loss of fish and seafood products annually (Ghaly et al., 2010).

In order to prolong the shelf life of fish and its products, different methods are employed. Freezing has been one of the most commonly practiced technique for storing fish as it keeps the fish moist, glossy and prevent it from dehydration (Jain, 2007). However, this method is not effective to address the quality issues of fish. Generally known plastic and other synthetic derivatives are extensively used for packing and storage of fish. However, these plastic products are highly dangerous causing environmental pollution issues (Aider, 2010). To overcome aforementioned problems, research has now been oriented towards adoption of new, natural biodegradable preservatives that can extend the shelf life of fish. Additionally, preservative material must have essential antimicrobial property that helps to maintain the quality of food (Dutta et al., 2009).

Edible coating is found effective in this regard; aiding to improve the quality of food by preventing discolouration, reducing the loss of water content and decreasing the bad aroma. They have capacity to keep proteins functional and prevent lipid from oxidation (Arancibia et al., 2015) as well as act as barrier against water loss, light and oxygen. These coatings also protect fish from other hazardous environmental factors that are responsible for faster spoilage of fish products (Gennadios et al., 1997).

Chitosan is a natural biopolymer, which is obtained from deacetylation of chitin (No et al., 2007). It is non-toxic, non-allergic, antibacterial, anti-oxidative and antifungal in nature and studies have suggested it to be less harmful towards mammalian cells (Ramezani et al., 
2015). The biodegradable nature and film forming property of chitosan makes it a preferable choice for use as a food preservative (Fan et al., 2009). Furthermore, it decreases lipid oxidation in flesh (Gennadios et al., 1997). Use of chitosan is also appreciated as it appears to prevent diseases such as diabetes mellitus, high blood pressure, cancer and arthritis in humans (Lodhi et al., 2014; Azuma et al., 2015).

Rohu (Labeo rohita) is one of the most important freshwater species, belonging to the family Cyprinidae. It is basically an omnivore and a column feeder (Azim et al., 2001). Fast growth rate, high market value and growing consumer demand of rohu makes it a strong candidate species for farming. It is extensively cultured in China, Vietnam, Indonesia, Thailand, Philippines, India, Bangladesh and Pakistan (Dewan et al., 1977). Information regarding the effect of chitosan on rohu meat during refrigerated storage is lacking and hence the present study was undertaken to assess the efficiency of chitosan coating in enhancing the shelf stability and quality of rohu (L. rohita) during chilled storage.

\section{Materials and methods}

\section{Sample preparation}

Samples of rohu having average size of $800 \mathrm{~g}$ were collected from Government Fish Farm in Sargodha, Pakistan. Live fishes were transported to the laboratory immediately upon harvest under oxygenated conditions. Upon arrival, fishes were immediately dressed and filleted free of blood, viscera, scales and skin. All fillets were scrubbed under fresh running water in order to remove mud, debris and fouling organisms if any adhering to the fish fillets. Fillets were randomly divided into five groups and dip treated for two hours in different concentrations of chitosan solutions: (i) Group $\mathrm{R}_{1}$ - untreated/control, Group $\mathrm{R}_{2}$ - treated with $0.1 \%$, Group $\mathrm{R}_{3}-0.25 \%$, Group $\mathrm{R}_{4}-0.5 \%$ and Group $\mathrm{R}_{5}-1 \%$ chitosan. Fillets were further drained and carefully packed in clean polyethylene bags separately and stored at $4^{\circ} \mathrm{C}$ for 30 days. To check the overall quality of fish fillets, sensory and chemical analyses were performed at 10 day intervals.

\section{Preparation of chitosan based edible coatings}

Chitosan powder (having 80-85\% degree of deacetylation and $126.2 \mathrm{kDa}$ molecular weight) was procured from VWR International, USA. Different concentrations of chitosan solution $(0.1,0.25,0.5$ and $1 \%$ $\mathrm{w} / \mathrm{w})$ were prepared in glacial acetic acid. For this, 1.25, 2.5, 5 and $10 \mathrm{~g}$ of chitosan powder was dissolved separately in $900 \mathrm{ml}$ of distilled water each, respectively; stirred for $10 \mathrm{~min}$ and further $10 \mathrm{ml}$ of glacial acetic acid was added to the mixture; solutions were again stirred for $2 \mathrm{~h}$ and final solutions each of $1000 \mathrm{ml}$ were made up with distilled water (Fan et al., 2009).

\section{Chemical analysis}

Water holding capacity (WHC) of fish muscle, as raw and cooked $\left(65^{\circ} \mathrm{C}, 20 \mathrm{~min}\right)$ form was determined gravimetrically by taking weight difference of samples with and without exudates. WHC was determined from percentage of the retained liquid with respect to initial water content as per the method described by Dunn et al. (2007). Protein extractability was measured following the methodology by Gornall et al. (1949) and absorbance determined at $540 \mathrm{~nm}$. Thiobarbituric acid reactive substances (TBARS) were determined in fish samples at $530 \mathrm{~nm}$ using spectrophotometer following the methodology of Gatta et al. (2000). pH of filtrates were measured using a digital $\mathrm{pH}$ meter (Ohaus starter 3100) (Fan et al., 2009).

\section{Sensory analysis}

Sensory analysis of the samples was carried out by five trained panelists, using 5-point hedonic scale for parameters viz., colour, odour, texture and taste with scale ranging from 1 (dislike extremely) to 5 (being like extremely). The samples were served in covered plate after cooking for $20 \mathrm{~min}$ at $98^{\circ} \mathrm{C}$ in oven and cooling for 2 min. Sensory acceptance limit for rejection was kept as 4.0 , below which the sample was considered to be unacceptable (Ojagh et al., 2010).

\section{Bacteriological analysis}

Total viable count (TVC) and psychrotrophic count (PTC) was determined following the method of Sallam (2007).

\section{Statistical analysis}

Five levels of chitosan treatments and four levels of storage time were employed for the study. Mean values \pm standard deviation was determined for each treatment done in triplicate and data were analysed by ANOVA. The least significant difference (LSD) was used to determine the difference between mean values $(\mathrm{p}<0.05)$.

\section{Results and discussion}

\section{Water holding capacity}

Water holding capacity (WHC) is a qualitative parameter defined as the ability of fish muscle to retain water in raw and cooked meat systems, imperiled to external force (Risvik, 1994). Initially during storage, there was no significant difference in the WHC in all 
treatments. A distinct drop in WHC was observed for all samples with increase in storage period (Table 1). This decrease in WHC value suggests denaturation of proteins during refrigeration. This reason could be explained by the fact that in muscle, myofibrillar protein network contains large amount of water and low storage temperature affects the protein structure (Duun and Rustad, 2007). The lowest value of WHC was seen in control rohu fillet samples and the highest value was recorded for $1 \%$ chitosan treated samples. Generally, decline in WHC values of chitosan coated rohu samples was significantly lower $(p<0.05)$ than the control samples. These results are in agreement to Gallart-Jornet et al. (2007) who studied WHC values in ice stored fish muscle. The higher WHC values of chitosan coated samples could be attributed to the relative polarity of this biopolymer. Moreover, chitosan coating acted as a moisture sacrificing agent instead of moisture barrier and thus, chitosan proved very effective in maintaining the moisture content of marine fish products until evaporation of its own moisture (Mohan et al., 2012).

\section{Soluble proteins}

Fish muscle proteins are important to judge the quality of fish meat (Hultmann and Rustad, 2004). In the current study, water extractable protein (WEP) and salt extractable protein (SEP) were analysed. The WEP values decreased during the period of chilled storage in all the four treatments, with $1 \%$ chitosan treatment demonstrating the highest values as compared to $0.1,0.25$ and $0.5 \%$ chitosan treatments (Table 1 ). These results were supported by the findings of Siddaiah et al. (2001) who reported decrease in the value of WEP in deboned fillets of silver carp (Hypophthalmichthys molitrix).

In fish, myofibrillar proteins undergo denaturation process during refrigerated storage, which results in lower extractability of proteins. Initial SEP values indicated the acceptable quality of fish muscle and non-significant differences among treatments. However, during storage, a decline in SEP values was observed with the gradual decrease in muscle quality of rohu fillets. Untreated rohu fillets presented lowest SEP values, while 1\% chitosan treated samples represented highest values throughout the storage period (Table 1). In contrary to these results, a significant rise in the values of WEP and SEP was reported in Atlantic salmon (Salmo sala) by Hultmann and Rustad (2004). However, in a study carried out by Dunn and Rustad (2007), significantly high level of WEP than that of SEP was observed during refrigerated storage of cod (Gadus morhua) fillets.

The low content of extractable proteins in uncoated samples (control) might be due to degradation of protein by the activation of endogenous enzymes and spoilage bacteria which affect the muscle protein and produce volatile basic nitrogenous compounds (Ramezani et al., 2015). In muscle tissue, chilled storage also leads to

Table 1. Chemical parameters of chitosan coated rohu fillets during refrigerated storage for 30 days

\begin{tabular}{|c|c|c|c|c|c|c|}
\hline Parameter & Storage days & $0 \%$ (Control) & $0.1 \%$ & $0.25 \%$ & $0.5 \%$ & $1 \%$ \\
\hline \multirow[t]{4}{*}{ WHC (\%) } & 0 & $9.74 \pm 0.03^{\mathrm{a}}$ & $9.75 \pm 0.04^{\mathrm{a}}$ & $9.74 \pm 0.01^{\mathrm{a}}$ & $9.71 \pm 0.01^{\mathrm{a}}$ & $9.74 \pm 0.01^{\mathrm{a}}$ \\
\hline & 10 & $6.87 \pm 0.06^{\mathrm{b}}$ & $7.17 \pm 0.03^{b}$ & $7.49 \pm 0.03^{b}$ & $7.98 \pm 0.04^{b}$ & $8.14 \pm 0.03^{b}$ \\
\hline & 20 & $4.81 \pm 0.02^{\mathrm{c}}$ & $5.93 \pm 0.02^{\mathrm{c}}$ & $6.19 \pm 0.02^{\mathrm{c}}$ & $6.36 \pm 0.02^{\mathrm{c}}$ & $6.52 \pm 0.02^{\mathrm{c}}$ \\
\hline & 30 & $3.89 \pm 0.02^{\mathrm{d}}$ & $3.99 \pm 0.04^{\mathrm{d}}$ & $4.19 \pm 0.05^{\mathrm{d}}$ & $4.44 \pm 0.02^{\mathrm{d}}$ & $4.61 \pm 0.02^{\mathrm{d}}$ \\
\hline \multirow[t]{4}{*}{ WEP $\left(\mathrm{g} 100 \mathrm{~g}^{-1}\right)$} & 0 & $5.82 \pm 0.02^{\mathrm{a}}$ & $5.81 \pm 0.02^{\mathrm{a}}$ & $5.78 \pm 0.02^{\mathrm{a}}$ & $5.81 \pm 0.03^{\mathrm{a}}$ & $5.80 \pm 0.02^{\mathrm{a}}$ \\
\hline & 10 & $5.22 \pm 0.03^{\mathrm{b}}$ & $5.29 \pm 0.01^{\mathrm{b}}$ & $5.33 \pm 0.01^{\mathrm{b}}$ & $5.37 \pm 0.02^{\mathrm{b}}$ & $5.45 \pm 0.04^{\mathrm{b}}$ \\
\hline & 20 & $4.56 \pm 0.02^{\mathrm{c}}$ & $4.65 \pm 0.02^{\mathrm{c}}$ & $4.71 \pm 0.01^{\mathrm{c}}$ & $4.80 \pm 0.01^{\mathrm{c}}$ & $5.00 \pm 0.01^{\mathrm{c}}$ \\
\hline & 30 & $4.29 \pm 0.01^{\mathrm{d}}$ & $4.37 \pm 0.03^{\mathrm{d}}$ & $4.42 \pm 0.01^{\mathrm{d}}$ & $4.50 \pm 0.01^{\mathrm{d}}$ & $4.64 \pm 0.02^{\mathrm{d}}$ \\
\hline \multirow[t]{4}{*}{ SEP $\left(\right.$ g $\left.100 \mathrm{~g}^{-1}\right)$} & 0 & $13.39 \pm 0.02^{\mathrm{a}}$ & $13.39 \pm 0.02^{\mathrm{a}}$ & $13.41 \pm 0.04^{\mathrm{a}}$ & $13.41 \pm 0.04^{\mathrm{a}}$ & $13.44 \pm 0.02^{\mathrm{a}}$ \\
\hline & 10 & $11.49 \pm 0.73^{b}$ & $12.12 \pm 0.01^{\mathrm{b}}$ & $12.46 \pm 0.03^{b}$ & $12.75 \pm 0.02^{\mathrm{b}}$ & $13.04 \pm 0.04^{\mathrm{b}}$ \\
\hline & 20 & $10.28 \pm 0.03^{\mathrm{c}}$ & $10.93 \pm 0.04^{\mathrm{c}}$ & $11.11 \pm 0.03^{\mathrm{c}}$ & $11.35 \pm 0.02^{\mathrm{c}}$ & $11.65 \pm 0.02^{\mathrm{c}}$ \\
\hline & 30 & $9.17 \pm 0.02^{\mathrm{d}}$ & $9.33 \pm 0.02^{\mathrm{d}}$ & $9.61 \pm 0.02^{\mathrm{d}}$ & $10.01 \pm 0.06^{\mathrm{d}}$ & $10.42 \pm 0.01^{\mathrm{d}}$ \\
\hline \multirow[t]{4}{*}{ TBARS (mg MDA $\left.\mathrm{kg}^{-1}\right)$} & 0 & $0.34 \pm 0.02^{\mathrm{d}}$ & $0.33 \pm 0.04^{\mathrm{d}}$ & $0.33 \pm 0.03^{\mathrm{d}}$ & $0.33 \pm 0.05^{\mathrm{d}}$ & $0.33 \pm 0.02^{\mathrm{d}}$ \\
\hline & 10 & $1.08 \pm 0.04^{\mathrm{c}}$ & $0.81 \pm 0.02^{\mathrm{c}}$ & $0.71 \pm 0.02^{\mathrm{c}}$ & $0.60 \pm 0.01^{\mathrm{c}}$ & $0.43 \pm 0.02^{c}$ \\
\hline & 20 & $2.28 \pm 0.02^{\mathrm{b}}$ & $1.05 \pm 0.02^{\mathrm{b}}$ & $0.91 \pm 0.02^{\mathrm{b}}$ & $0.68 \pm 0.02^{\mathrm{b}}$ & $0.61 \pm 0.03^{\mathrm{b}}$ \\
\hline & 30 & $3.14 \pm 0.03^{\mathrm{a}}$ & $1.39 \pm 0.01^{\mathrm{a}}$ & $1.01 \pm 0.03^{\mathrm{a}}$ & $0.87 \pm 0.02^{\mathrm{a}}$ & $0.74 \pm 0.02^{\mathrm{a}}$ \\
\hline \multirow[t]{4}{*}{$\mathrm{pH}$} & 0 & $5.73 \pm 0.03^{\mathrm{d}}$ & $5.75 \pm 0.03^{\mathrm{d}}$ & $5.75 \pm 0.02^{\mathrm{d}}$ & $5.74 \pm 0.05^{\mathrm{d}}$ & $5.72 \pm 0.03^{\mathrm{d}}$ \\
\hline & 10 & $5.97 \pm 0.04^{c}$ & $5.87 \pm 0.02^{\mathrm{c}}$ & $5.87 \pm 0.02^{\mathrm{c}}$ & $5.82 \pm 0.01^{\mathrm{c}}$ & $5.78 \pm 0.01^{\mathrm{c}}$ \\
\hline & 20 & $6.29 \pm 0.02^{\mathrm{b}}$ & $6.13 \pm 0.02^{b}$ & $6.02 \pm 0.01^{b}$ & $5.99 \pm 0.01^{b}$ & $5.91 \pm 0.01^{\mathrm{b}}$ \\
\hline & 30 & $6.72 \pm 0.03^{\mathrm{a}}$ & $6.52 \pm 0.04^{\mathrm{a}}$ & $6.43 \pm 0.02^{\mathrm{a}}$ & $6.34 \pm 0.02^{\mathrm{a}}$ & $6.06 \pm 0.03^{\mathrm{a}}$ \\
\hline
\end{tabular}

WHC: Water holding capacity; WEP: Water extractable proteins; SEP: Salt extractable proteins; TBARS: Thiobarbituric acid reactive substances 
denaturation of the protein resulting in low salt extractable protein especially myofibrillar protein. This decrease in protein values could be attributed to denaturation of proteins (Duun and Rustad, 2007).

TBARS

Basically, TBARS is used to measure the amount of malonaldehyde which is produced during the second stage auto-oxidation process of lipids in which peroxides are converted into aldehydes and ketones (Ramezani et al., 2015). The TBARS values increased significantly $(\mathrm{p}<0.05)$ during storage time in all lots of rohu fillets. The fillets treated with 0.5 and $1 \%$ chitosan showed a decrease in the rate of increase of TBARS values as compared to control (Table 1). According to Wenjiao et al. (2014) value of 1-2 mg MDA kg-1 is regarded as maximal permissible limit beyond which fish usually develops an unpleasant odour. After 30 days, TBARS value reached up to 3.135 mg MDA kg-1 for control sample, surpassing the upper acceptability limit. This rise in value could be attributed to low storage temperature, which was responsible for partial dehydration of fish and enhanced oxidation of unsaturated fatty acids (Kilincceker et al., 2009). In the support of current findings, increase in TBARS values was also reported in sardine, blue whiting and silver carp fillets during refrigerated storage (Chaijan et al., 2006; Jezek and Buchtova, 2011). Similarly, Souza et al. (2010) also reported that the fish samples coated with chitosan presented a significant reduction in TBARS values after 9 days of storage, when compared to control samples.

$p H$

$\mathrm{pH}$ is one of the most widely used key to find out the alkalinity and acidity of flesh (Li et al., 2016). Change in $\mathrm{pH}$ value can be used as a spoilage index of fish meat. In the present study, an increase in the $\mathrm{pH}$ value was observed for the control samples till the end of the experimental period. The subsequent rise in the $\mathrm{pH}$ might be related to the increase in production of volatile basic components such as ammonia and trimethylamine by the activities of either endogenous or microbial enzymes (Li et al., 2012). However, chitosan treated samples showed significantly lower $\mathrm{pH}$ values $(\mathrm{p}<0.05)$ than untreated samples. Further, $1 \%$ chitosan treatment was more effective to limit the change in $\mathrm{pH}$ of rohu fillets during storage. This phenomenon could be due to the acidic nature of chitosan solution. Some researchers also observed that different chitosan treatments delayed the rise in $\mathrm{pH}$ value of different fishes like silver carp (Ramezani et al., 2015), lingcod (Duan et al., 2010) and white shrimp (Yuan et al., 2016).

\section{Sensory evaluation}

Sensory analysis is the most important parameter to assess the quality of fish meat (Mohan et al., 2012). The sensory evaluation results in terms of texture, colour, odour and taste using 5-point hedonic scale are represented in Table 2. Initially during the beginning of chilled storage, there were no significant differences among organoleptic attributes such as texture, colour, odour and taste, which clearly indicated that chitosan had no negative impact on organoleptic attributes. The sensory scores for all treatments gradually decreased with extended storage time. The coated rohu fillets exhibited significantly slower decrease in values as compared to control samples. Among all treatments, 1\% chitosan was found more effective in delaying the spoilage rate of fish, reflective in the sensory score as well. This might be

Table 2. Sensory attributes of chitosan coated rohu fillets during refrigerated storage for 30 days

\begin{tabular}{|c|c|c|c|c|c|c|}
\hline Parameter & Storage days & $0 \%$ (Control) & $0.1 \%$ & $0.25 \%$ & $0.5 \%$ & $1 \%$ \\
\hline \multirow[t]{4}{*}{ Texture } & 0 & $5.45 \pm 0.07^{\mathrm{a}}$ & $5.50 \pm 0.01^{\mathrm{a}}$ & $5.45 \pm 0.07^{\mathrm{a}}$ & $5.45 \pm 0.07^{\mathrm{a}}$ & $5.45 \pm 0.07^{\mathrm{a}}$ \\
\hline & 10 & $4.25 \pm 0.07^{b}$ & $4.30 \pm 0.02^{b}$ & $4.65 \pm 0.03^{b}$ & $5.00 \pm 0.14^{b}$ & $5.15 \pm 0.02^{b}$ \\
\hline & 20 & $3.25 \pm 0.21^{\mathrm{c}}$ & $3.70 \pm 0.14^{\mathrm{c}}$ & $4.05 \pm 0.07^{\mathrm{c}}$ & $4.45 \pm 0.07$ & $4.75 \pm 0.07$ \\
\hline & 30 & $2.45 \pm 0.07^{\mathrm{d}}$ & $3.15 \pm 0.07^{\mathrm{d}}$ & $3.70 \pm 0.14^{\mathrm{d}}$ & $3.95 \pm 0.07^{\mathrm{d}}$ & $4.20 \pm 0.05^{\mathrm{d}}$ \\
\hline \multirow[t]{4}{*}{ Odour } & 0 & $4.65 \pm 0.21^{\mathrm{a}}$ & $4.75 \pm 0.04^{\mathrm{a}}$ & $4.65 \pm 0.07^{\mathrm{a}}$ & $4.75 \pm 0.02^{\mathrm{a}}$ & $4.65 \pm 0.07^{\mathrm{a}}$ \\
\hline & 10 & $3.70 \pm 0.14^{\mathrm{b}}$ & $3.65 \pm 0.07^{b}$ & $3.85 \pm 0.07^{b}$ & $4.05 \pm 0.09^{b}$ & $4.15 \pm 0.07^{b}$ \\
\hline & 20 & $2.75 \pm 0.07^{\mathrm{c}}$ & $3.05 \pm 0.06^{\mathrm{c}}$ & $3.20 \pm 0.14^{\mathrm{c}}$ & $3.65 \pm 0.07^{\mathrm{c}}$ & $3.85 \pm 0.04^{\mathrm{c}}$ \\
\hline & 30 & $2.35 \pm 0.21^{\mathrm{d}}$ & $2.65 \pm 0.07^{d}$ & $2.80 \pm 0.14^{\mathrm{d}}$ & $3.15 \pm 0.03^{\mathrm{d}}$ & $3.45 \pm 0.07^{\mathrm{d}}$ \\
\hline \multirow[t]{4}{*}{ Colour } & 0 & $5.05 \pm 0.07^{\mathrm{a}}$ & $5.10 \pm 0.14^{\mathrm{a}}$ & $5.10 \pm 0.08^{\mathrm{a}}$ & $5.15 \pm 0.02^{\mathrm{a}}$ & $5.10 \pm 0.14^{\mathrm{a}}$ \\
\hline & 10 & $4.10 \pm 0.14^{b}$ & $4.15 \pm 0.07^{b}$ & $4.30 \pm 0.04^{b}$ & $4.45 \pm 0.07^{\mathrm{b}}$ & $4.65 \pm 0.07^{\mathrm{b}}$ \\
\hline & 20 & $3.35 \pm 0.21^{\mathrm{c}}$ & $3.65 \pm 0.07^{\mathrm{c}}$ & $3.95 \pm 0.07^{\mathrm{c}}$ & $4.00 \pm 0.14^{\mathrm{c}}$ & $4.10 \pm 0.14^{\mathrm{c}}$ \\
\hline & 30 & $1.95 \pm 0.07^{\mathrm{d}}$ & $2.85 \pm 0.21^{\mathrm{d}}$ & $3.40 \pm 0.14^{\mathrm{d}}$ & $3.65 \pm 0.07^{\mathrm{d}}$ & $3.85 \pm 0.07^{\mathrm{d}}$ \\
\hline \multirow[t]{4}{*}{ Taste } & 0 & $5.05 \pm 0.07^{\mathrm{a}}$ & $5.15 \pm 0.07^{\mathrm{a}}$ & $5.15 \pm 0.07^{\mathrm{a}}$ & $5.20 \pm 0.14^{\mathrm{a}}$ & $5.10 \pm 0.12^{\mathrm{a}}$ \\
\hline & 10 & $4.40 \pm 0.14^{\mathrm{b}}$ & $4.30 \pm 0.14^{\mathrm{b}}$ & $4.55 \pm 0.09^{b}$ & $4.75 \pm 0.07^{b}$ & $4.85 \pm 0.09^{b}$ \\
\hline & 20 & $3.60 \pm 0.14^{\mathrm{c}}$ & $3.80 \pm 0.15^{\mathrm{c}}$ & $3.90 \pm 0.02^{\mathrm{c}}$ & $4.05 \pm 0.03^{\mathrm{c}}$ & $4.50 \pm 0.14^{\mathrm{c}}$ \\
\hline & 30 & $2.45 \pm 0.07^{\mathrm{d}}$ & $2.95 \pm 0.07^{\mathrm{d}}$ & $3.35 \pm 0.21^{\mathrm{d}}$ & $3.75 \pm 0.07^{\mathrm{d}}$ & $3.90 \pm 0.11^{\mathrm{d}}$ \\
\hline
\end{tabular}


due to the antimicrobial, antioxidant and oxygen barrier properties of chitosan. Similar results were also reported for pacific oyster, silver carp and oilsardine (Cao et al., 2009; Fan et al., 2009; Mohan et al., 2012).

\section{Bacteriological analysis}

Changes in total viable count (TVC) and psychrotrophic count (PTC) of rohu fillets during refrigerated storage are shown in Fig. 1 and 2. The TVC and PTC $\left(\log _{10} \mathrm{CFU} \mathrm{\textrm {g } ^ { - 1 }}\right)$ of the untreated fillets were higher than the fillets treated with different concentrations of chitosan. The lower TVC and PTC of chitosan treated fillets indicated that chitosan coating reduced the microbial population. TVC and PTC were lowest in fillets treated with $1 \%$ chitosan. The antimicrobial properties of chitosan coating have been well stated in previous studies. Fernandez-Saiz et al. (2013) reported a significant $(p<0.05)$ increase of the lag phase and a decrease in the final microbial population. Lopez-Caballero et al. (2005) also documented that chitosan coating along with gelatin reduced the growth of Gram negative bacteria in fish. Other researchers also reported that the complex chitosan film reduced the growth of bacteria (Gomez-Estaca et al., 2010). The mechanism of antimicrobial action of chitosan could be related to interactions between the positively charged chitosan molecules and the negatively charged microbial cell membrane. In the present study, chitosan coating led to significant $(\mathrm{p}<0.05)$ reduction in the TVC and PTC of rohu fillets during refrigerated storage.

Chemical, microbial and sensory evaluation results proved chitosan to be very effective as a natural preservative to maintain the quality of rohu fillets. Current study concluded that $1 \%$ chitosan coating on rohu fillets can lead to retention of good quality characteristics and extension of shelf life upto 30 days during chilled storage.

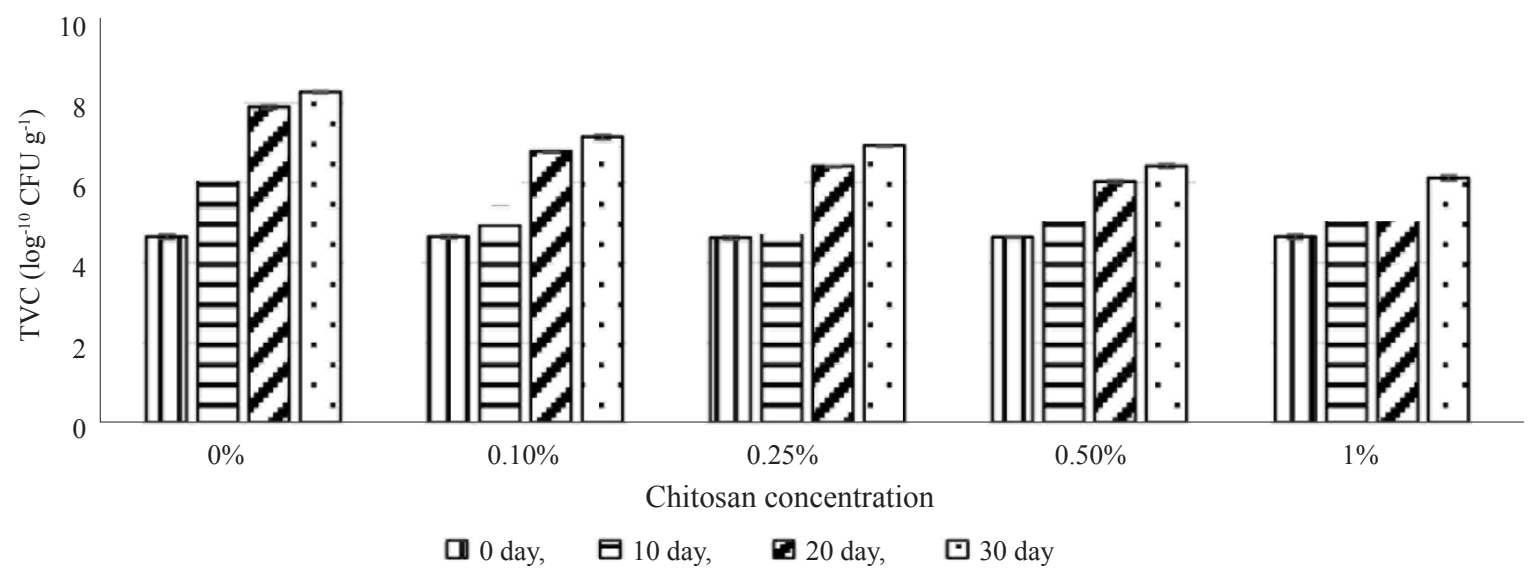

Fig. 1. Changes in total viable counts (TVC) of fish samples treated with different concentrations of chitosan during refrigerated storage

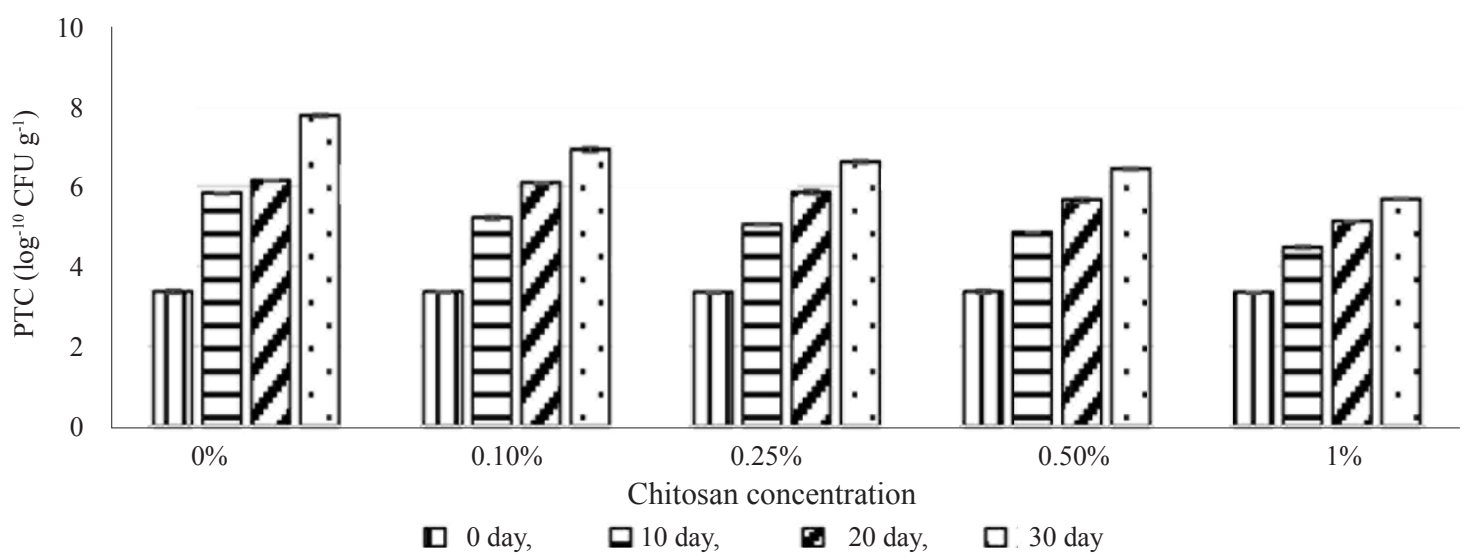

Fig. 2. Changes in psychrotrophilic counts (PTC) of fish samples treated with different concentrations of chitosan during refrigerated storage 


\section{References}

Aider, M. 2010. Chitosan application for active bio-based films production and potential in the food industry. LWT-Food Sci. Technol., 43(6): 837-842. https://doi.org/10.1016/j. lwt.2010.01.021.

Alishahi, A. and Aider, M. 2012. Applications of chitosan in the seafood industry and aquaculture: a review. Food Bioprocess Technol., 5(3): 817-830. DOI: 10.1007/s11947011-0664-x.

Arancibia, M. Y., Lopez-Caballero, M. E., Gomez-Guillen, M. C. and Montero, P. 2015. Chitosan coatings enriched with active shrimp waste for shrimp preservation. Food Control, 54: 259-266. https://doi.org/10.1016/j.foodcont. 2015.02.004.

Azim, M. E., Wahab, M. A., Van Dam, A. A., Beveridge, M. C. M. and Verdegem, M. C. J. 2001. The potential of periphytonbased culture of two Indian major carps, rohu Labeo rohita (Hamilton) and gonia Labeo gonius (Linnaeus). Aquac. Res., 32(3): 209-216. https://doi.org/10.1046/j.1365-2109. 2001.00549.x.

Azuma, K., Osaki, T., Minami, S. and Okamoto, Y. 2015. Anti-cancer and anti-inflammatory properties of chitin and chitosan oligosaccharides. J. Funct. Biomater., 6(1): 33-49. doi: 10.3390/jfb6010033.

Calder, P. C. 2004. N-3 Fatty acids and cardiovascular disease: evidence explained and mechanisms explored. Clin. Sci., 107(1): 1-11. DOI: 10.1042/CS20040119.

Cao, R., Xue, C. H. and Liu, Q. 2009. Changes in microbial flora of Pacific oysters (Crassostrea gigas) during refrigerated storage and its shelf-life extension by chitosan. Int. J. Food. Microbiol., 131(2), 272-276. DOI: 10.1016/j.ijfoodmicro. 2009.03.004

Chaijan, M., Benjakul, S., Visessanguan, W. and Faustman, C. 2006. Changes of lipids in sardine (Sardinella gibbosa) muscle during iced storage. Food Chem., 99(1): 83-91. DOI: 10.1016/j.foodchem.2005.07.022.

Dewan, S., Ali, M. M. and Islam, M. A. 1977. Studies on the size and patterns of feeding of fry and fingerlings of three major carps viz., Labeo rohita, Catla catla and Cirrhina mrigala. Bangl.J. Agric., 2(2): 223-228.

Duun, A. S. and Rustad, T. 2007. Quality changes during super chilled storage of cod (Gadus morhua) fillets. Food. Chem., 105(3): 1067-1075. DOI: 10.1016/j. foodchem.2007.05.020.

Duan, J., Cherian, G. and Zhao, Y. 2010. Quality enhancement in fresh and frozen ling cod (Ophiodon elongates) fillets by employment of fish oil incorporated chitosan coatings. Food Chem., 119(2): 524-532. DOI: 10.1016/j. foodchem.2009.06.055.

Dutta, P. K., Tripathi, S., Mehrotra, G. K. and Dutta, J. 2009. Perspectives for chitosan based antimicrobial films in food applications. Food. Chem., 114(4): 1173-1182. DOI: 10.1016/j.foodchem.2008.11.047.
Fan, W., Sun, J., Chen, Y., Qiu, J., Zhang, Y. and Chi, Y. 2009. Effects of chitosan coating on quality and shelf life of silver carp during frozen storage. Food. Chem., 115(1): 66-70. DOI: 10.1016/j.foodchem.2008.11.060.

Gallart-Jornet, L., Barat, J. M., Rustad, T., Erikson, U., Escriche, I. and Fito, P. 2007. A comparative study of brine salting of Atlantic cod (Gadus morhua) and Atlantic salmon (Salmo salar). J. Food Engg, 79(1): 261-270. https://doi. org/10.1016/j.jfoodeng.2006.01.053.

Gatta, P. P., Pirini, M., Testi, S., Vignola, G. and Monetti, P. G 2000. The influence of different levels of dietary vitamin $\mathrm{E}$ on seabass Dicentrarchus labrax flesh quality. Aquac. Nutr., 6(1): 47-52. https://doi.org/10.1046/j.1365-2095. 2000.00127.x.

Gennadios, A., Hanna, M. A. and Kurth, L. B. 1997. Application of edible coatings on meats, poultry and seafoods: a review. LWT-Food Sci. Technol., 30(4): 337-350.

Ghaly, A. E., Dave, D., Budge, S. and Brooks, M. S. 2010. Fish spoilage mechanisms and preservation techniques. Am. $J$. Appl. Sci., 7(7): 859-877. DOI : 10.3844/ajassp.2010. 859.877.

Gomez-Estaca, J., Lopez de Lacey, A., Lopez-Caballero, M. E., Gomez-Guillen, M. C. and Montero, P. 2010. Biodegradable gelatin-chitosan films incorporated with essential oils as antimicrobial agents for fish preservation. Food Microbiol., 27: 889-896. DOI: 10.1016/j.fm.2010.05.012.

Gornall, A. G., Bardawill, C. J. and David, M. M. 1949. Determination of serum proteins by means of the biuret reaction. J. Biol. Chem., 177(2): 751-766.

Gupta,A., Rai, D. K., Pandey, R. S. and Sharma, B. 2009. Analysis of some heavy metals in the riverine water, sediments and fish from river Ganges at Allahabad. Environ. Monit. Assess., 157(1): 449-458. DOI: 10.1007/s10661-008-0547-4.

Hultmann, L. and Rustad, T. 2004. Iced storage of Atlantic salmon (Salmo salar): effects on endogenous enzymes and their impact on muscle proteins and texture. Food Chem., 87(1): 31-41.

Jain, K. K. 2007. Nano-biotechnology-based drug delivery to the central nervous system. Neurodegenerative Dis., 4(4): 287-291. doi: 10.1159/000101884

Jeyasekaran, G., Ganesan, P., Anandaraj, R., Shakila, R. J. and Sukumar, D. 2006. Quantitative and qualitative studies on the bacteriological quality of Indian white shrimp (Penaeus indicus) stored in dry ice. Food Microbiol., 23(6): 526-533. DOI: $10.1016 /$ j.fm.2005.09.009.

Jezek, F. and Buchtova, H. 2007. Physical and chemical changes in fresh chilled muscle tissue of common carp (Cyprinus carpio L.) packaged in a modified atmosphere. Acta Vet. Brno., 76: 83-92. https://doi.org/10.2754/avb 200776S8S083.

Kilincceker, O., Dogan, I. S. and Kucukoner, E. 2009. Effect of edible coatings on the quality of frozen fish fillets. $L W T$ Food Sci. Technol., 42(4): 868-873. 
Li, T., Li, J., Hu, W., Zhang, X., Li, X. and Zhao, J. 2012. Shelf life extension of crucian carp (Carassius auratus) using natural preservatives during chilled storage. Food Chem., 135(1): 140-145.

Li, X. X., Tian, X., Cai, L. Y., Lv, Y. F., Liu, X. F. and Li, J. R. 2016. Effects of chitosan and hawthorn flavonoid coating on quality and shelf life of flounder (Paralichthys olivaceus) fillets during refrigerated storage. J. Food Process Preserv., 41(2): 1-9. https://doi.org/10.1111/jfpp.12831.

Lodhi, G., Kim, Y. S., Hwang, J. W., Kim, S. K., Jeon, Y. J., Je, J. Y., Ahn, C. B., Moon, S. H., Jeon, B. T. and Park, P. J. 2014. Chito-oligosaccharide and its derivatives: preparation and biological applications. Bio. Med. Res. Int., 2014. doi:10.1155/2014/654913.

Lopez-Caballero, M., Gomez-Guillen, M., Perez-Mateos, M. and Montero, P. A. 2005. Chitosan-gelatin blend as a coating for fish patties. Food Hydrocolloids, 19: 303-311.

Mohan, C. O., Ravishankar, C. N., Lalitha, K. V. and Gopal, T. S. 2012. Effect of chitosan edible coating on the quality of double filleted Indian oil sardine (Sardinella longiceps) during chilled storage. Food Hydrocolloids, 26(1): 167-174.

No, H. K., Meyers, S. P., Prinyawiwatkul, W. and Xu, Z. 2007. Applications of chitosan for improvement of quality and shelf life of foods: a review. J. Food. Sci., 72(5): 87-100. DOI: $10.1111 / \mathrm{j} .1750-3841.2007 .00383 . x$.

Ojagh, S. M., Rezaei, M., Razavi, S. H. and Hosseini, S. M. H. 2010. Effect of chitosan coatings enriched with cinnamon oil on the quality of refrigerated rainbow trout. Food Chem., 120(1): 193-198. DOI: 10.1016/j.foodchem.2009.10.006.

Ramezani, M., Haddad, J. and Geroliminis, N. 2015a. Dynamics of heterogeneity in urban networks: aggregated traffic modeling and hierarchical control. Transp. Res. Part B: Methodol., 74: 1-19.

Ramezani, Z., Zarei, M. and Raminnejad, N. 2015b. Comparing the effectiveness of chitosan and nano-chitosan coatings on the quality of refrigerated silver carp fillets. Food Control, 51: 43-48.

Risvik, E. 1994. Sensory properties and preferences. Meat Sci., 36(1): 67-77. doi: 10.1016/0309-1740(94)90034-5.

Sallam, K. I. 2007. Antimicrobial and antioxidant effects of sodium acetate, sodium lactate and sodium citrate in refrigerated sliced salmon. Food Control, 18: 566-575. DOI: 10.1016/j.foodcont.2006.02.002.

Siddaiah, D., Reddy, G. V. S., Raju, C. V. and Chandrasekhar, T. C. 2001. Changes in lipids, proteins and kamaboko forming ability of silver carp (Hypophthalmichthys molitrix) mince during frozen storage. Food Res. Int., 34(1): 47-53.

Souza, B. W., Cerqueira, M. A., Ruiz, H. A., Martins, J. T., Casariego, A., Teixeira, J. A. and Vicente, A. A. 2010. Effect of chitosan based coatings on the shelf life of salmon (Salmo salar). J. Agric. Food Chem., 58(21): 11456-11462. doi: 10.1021/jf102366k.

Tayel, A. A. 2016. Microbial chitosan as a bio preservative for fish sausages. Int. J. Biol. Macromol., 93: 41-46. doi: 10. 1016/j.ijbiomac.2016.08.061.

Wenjiao, F., Yongkui, Z., Yunchuan, C., Junxiu, S. and Yuwen, Y. 2014. TBARS predictive models of pork sausages stored at different temperatures. Meat Sci., 96(1): 1-4. doi: 10. 1016 /j.meatsci.2013.06.025.

Yuan, G., Zhang, X., Tang, W. and Sun, H. 2016. Effect of chitosan coating combined with green tea extract on the melanosis and quality of Pacific white shrimp during storage in ice. Cy TA-J. Food., 14(1): 35-40. 